\title{
TALENT MANAGEMENT IN THE CONTEXT OF HUMAN CAPITAL
}

\author{
ROBERT BALCERZYK, ${ }^{1}$ DOROTA BALCERZYK ${ }^{2}$
}

General Tadeusz Kościuszko Military Academy of Land Forces in Wrocław, Management Department, POLAND

${ }^{1}$ e-mail: robert.balcerzyk@awl.edu.pl

${ }^{2}$ e-mail: dorota.balcerzyk@awl.edu.pl

\section{RECEIVED \\ ACCEPTED \\ JEL \\ CLASSIFICATION \\ KEYWORDS}

ABSTRACT
10 December 2018

28 December 2018

J24, M12, M54, 015

talent, talent management, competence, intellectual capital

The main objective of the article is to present the research on the talent management process in small and medium-sized companies in the Lower Silesian Voivodeship. The research was of a pilot nature. The article defines the essence of the concept of "talent", and describes and characterizes the "house" of the new generation of human resources as well. The results of research on understanding the term "talent" by respondents have been presented. Respondents' opinions on persons responsible for the implementation of development programs have been quoted. The diagnosis was conducted on the functioning of 'talent management' programs in companies employing the surveyed students. The article ends with a summary and presentation of the conclusions from the research.

\section{Introduction}

Over the last few decades, the dominant concepts of organization and management have undergone a kind of evolution. Since the 1950s the process of globalization, and thus also a gradual increase in the complexity of the environment of operating enterprises has been observed. The 1970s were a period of global orientation. The organization's environment has been stormy and turbulent. Strategic management has become a tool for 
streamlining organizations and management. The last decade of the twentieth century saw more radical changes in management. Knowledge management appeared as a dominant concept integrating all management subsystems. The approach to managing people has changed. People are currently treated as the most valuable "resource" of an organization. It is thanks to them that the organization gains an advantage over the competition. However, it should be noted that the same people constitute a "critical mass" in every organization. The development of employee competencies has become the key activity of the management staff. Managers recognize the importance of talents for the development and operation of an organization. The concept of talent management begins to function. Talent management is becoming an important element of the human capital management process.

\section{The essence of talent management}

In the literature on management sciences, the concept of talent is variously defined. The notion of "talent" derives from the Greek word talanton, which meant the unbearable burden for one person (Chełpa, 2015, p. 28). The concept of talent can be defined as innate abilities evolving as a result of undertaken actions into appropriate skills and passions, thanks to which an individual can create products or provide socially useful services, and which are subject to evaluation in terms of high quality, beauty or pleasure for the senses of a recipient at a level that is higher than average and difficult to meet by most other manufacturers or performers of a given product or service (Kopeć, 2012, p. 16).

According to A. Pocztowski, a talent is an individual who is guided by an internal goal, unchanged for a long period of time, and at the same time bringing his own goal to an organization (Pocztowski, 2008, p. 36). K. GłowackaStewart thinks alike and claims that "a talent is every person who can significantly influence the current and future achievements of their organization" (Głowacka-Stewart, 2016, p. 8). This definition shows that any employee in the organization may be a talent. This definition emphasizes both current results and achievements of an employee as well as his/her potential.

The concept of talent management deserves attention. According to T. Listwan, talent management is a set of activities referring to extremely talented people and undertaken for reasons of their development and efficiency as well as achieving the organization's goals (Antczak, 2010, p. 191).

In turn, Davis believes that talent management is about recruiting, proper training and development of employees, as well as retaining employees achieving excellent results in an uninterrupted and consistent manner. The talent management strategy is a well-thought-out, structured approach of a given company to recruit and retain employees, as well as train and develop talented individuals in an organization (Davis, 2010, p. 15).

$S$. Chełpa notes that a talent is constituted by a series of elements and he mentions general abilities (i.e. above-average intellectual potential), directional skills (skills related to specific areas of human functioning) and factors unrelated to thinking (achievement motivation, emotional maturity, mental resilience) among them (Chełpa, 2015, p. 26).

Talents can be directed in a homogeneous way, then they relate to one specific field and in this situation they are referred to as mono skills or special abilities. There are, however, cases that people's above average aptitudes refer to several dimensions of knowledge and skills - then these are multi skills manifested by multi talented people (Sękowski, 2004, p. 64). 
The concept of talents was popularized at the end of the last century. The development of modern technologies caused that the demand for employee talents exceeded their supply. This resulted in the employee talent market has become the most competitive one since the 1990s (Jabłoński, 2015, p. 35).

J. Kopeć distinguishes the following types of talents:

- critical talents,

- leadership talents,

- sales talent,

- talents in the field of knowledge acquisition and processing (Kopeć, 2012, p. 6).

Critical talents are the most valuable for an organization. They ensure effective and efficient functioning of an organization. In turn, with leadership talents, an organization is able to achieve an advantage over the competition. The managers' abilities may result in greater employee commitment to work thanks to trust in managers' decisions. This is essential when, for example, a company emerges from the crisis. In turn, most commercial companies operating in today's economy value sales talents more. It is about individual sales and the highest sales figures achieved by sales teams (heads of these groups). With the ever-growing excessive amount of information necessary to survive and achieve the organization's success, the importance of workers' knowledge is growing.

Employees in an organization occupy diverse positions and perform various functions (e.g. managerial, independent specialists or team leaders). Therefore, they can be differentiated according to various criteria, for example according to the position occupied in the organizational structure and tasks related to the creation of knowledge.

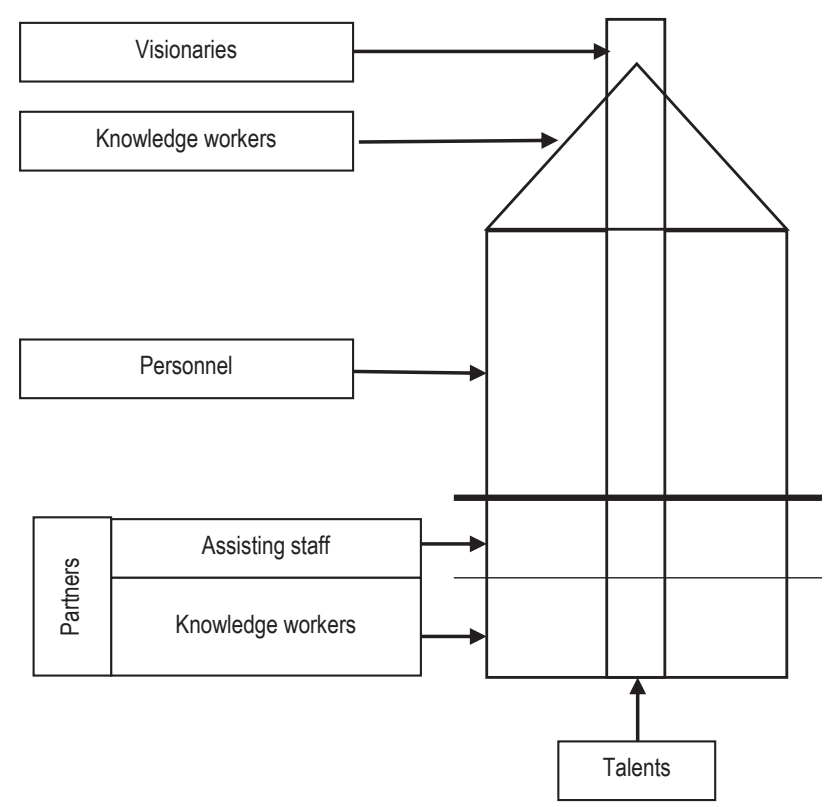

Figure 1. The "house" of the new generation of human resource

Source: Mikuła (2012), p. 22. 
B. Mikuła divides knowledge workers into three groups (Figure 1): knowledge practitioners (first line of business), knowledge constructors (medium-level management) and knowledge commanders -general management (Mikuła, 2012, p. 22).

One cross-sectional category of particularly talented people, the so-called talents, may be additionally identified within each of the indicated groups of people working for an organization. Examples of talented employees include:

a) technologists who carry out innovation on a global scale;

b) employees belonging to the personnel group performing simple work assisting independent specialists, but possessing high linguistic intelligence that gives them a special ability to learn and use foreign languages; these employees make a significant contribution to establishing new contacts with foreign companies, gaining new distribution channels and promoting goods;

c) a seller familiar with customer behavior, their expectations and desires, having an incredible ability to make contacts easily, who thus achieves the best sales results from the entire group of sellers;

d) an external consultant who, in addition to specialized knowledge in the field of organizational behavior, also has extensive emotional intelligence creating a talent that allows him/her to efficiently diagnose and solve problems underlying the functioning of the social working environment (Mikuła, 2012, pp. 22-24).

\section{Methods and characteristics of the research sample}

The following research methods were used in the studies presented in this article:

- the critical literature review method (literature in the field of talent management, employee development, management of knowledge),

- participant observation method (related to running one's own business),

- the analysis of secondary sources (studies of similar scope),

- diagnostic survey with company employees related to sub-functions of personnel management.

327 students participated in the study. These are students of part-time studies at three universities in the Lower Silesian Voivodeship. Women constituted the majority of the surveyed (75\%). Only every fourth respondent was a man (25\%). The structure of the studied group by gender is shown in Figure 2.

The respondents were young people aged $19-24$. They constituted $56 \%$ of the surveyed group. Almost one third of the surveyed students were between 25 to 35 years old (31\%). The lest numerous group were people over 40 years of age $(6 \%)$

Independent variables indicate that the research sample was composed of young people aged up to 29 years are. These people were at the stage of preparing for a career or early career, during which crystallization, narrowing the field of exploration and finalizing the choice of occupation occur. They appreciate the importance of intellectual capital as the most valuable resource of an organization. The capital consists mainly of their competences such as knowledge, skills, experience and attitudes, which are utilized in the work performed. Human capital is a component part of the intellectual capital of an organization. The latter is the sum of everything that everyone in the organization knows and what determines its competitive advantage. This has a huge impact on the organization's creativity and innovation. Therefore, personal development not only affects the growth of individual competences and the competitiveness of an individual on the labor market, but also guarantees a given organization an advantage over the competition. Figure 3 shows the age of respondents. 


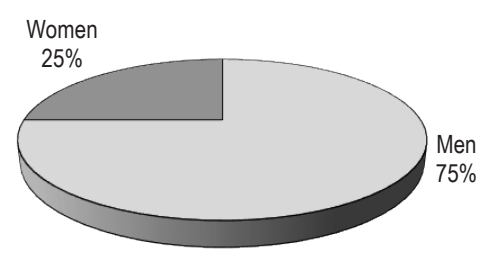

Figure 2. The research group with regard to gender

Source: own study.

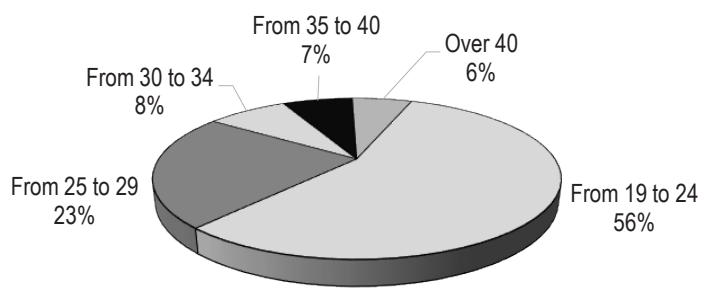

Figure 3. The research group with regard to age

Source: own study.

The vast majority of the surveyed group works in large companies employing over 100 persons (38.5\%). About $15.9 \%$ of the respondents are employed in companies with from 21 to 50 people, and $14.1 \%$ are employees of companies with from 51 to 100 workers. The research was carried out in higher education institutions outside Wrocław. The students are residents of villages and small towns. Therefore, the respondents are employees of small and medium enterprises. The division of the respondents' employment by the size of a company is displayed in Figure 4.

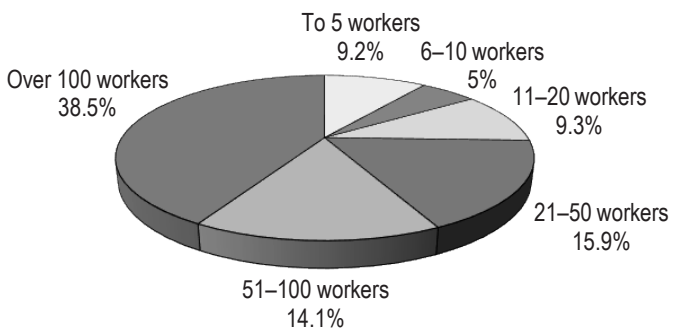

Figure 4. The respondents' place of employment with regard to a company size

Source: own study.

About $45.5 \%$ of the surveyed respondents are residents of small towns with up to 25 thousand inhabitants (Figure 5). Slightly less percentage, that is $30 \%$, is inhabitants of villages. A relatively small group of the respondents 
are inhabitants of towns with a population up to $50,000(7.4 \%)$. Only $1.6 \%$ of them are residents of larger cities. Therefore, the respondents are employees of small and medium enterprises.

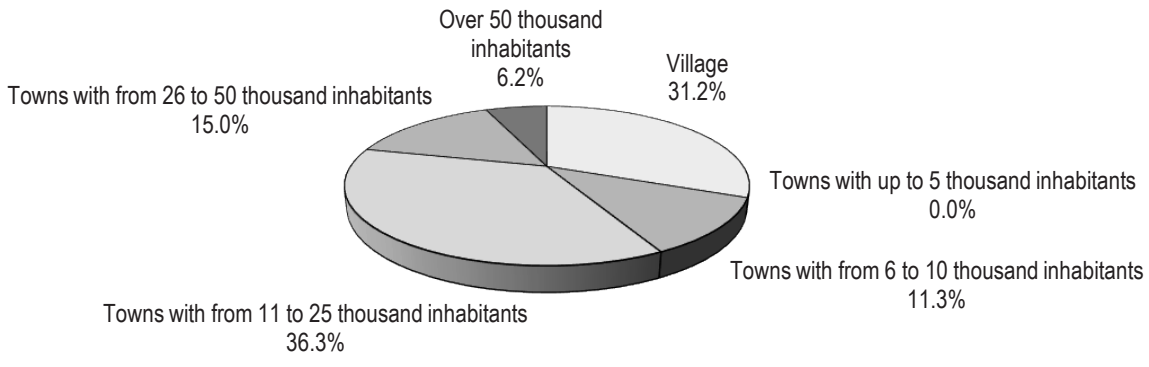

Figure 5. The respondents' places of residence

Source: own study.

\section{Functioning of talent management programs}

In the literature on management sciences, there are a variety of definitions of "talent". At the beginning of the research, an attempt was made to define the term "talent". The respondents' opinions on the meaning of the definition of "talent" are shown in Figure 6.

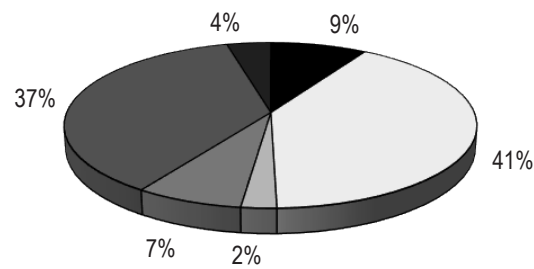

- A specialist, difficult to be replaced

$\square$ A person with high development potential, entrepreneurial, creative

$\square$ A person achieving the best results

$\square$ A person who can significantly influence current and future achievements of an organizationswojej organizacji

$\square$ A person with exceptional rare talents, e.g. an outstanding scientist naukowiec

a A person with unusual but superfluous abilities, not affecting the improvement of the lives of others or the functioning of an organization

Figure $\mathbf{6}$. The respondents' views on the meaning of the definition of "talent"

Source: own study.

Fewer than half of the respondents $(41 \%)$ identify the word "talent" with a person endowed with high development potential, entrepreneurial and creative. Slightly less, more than $37 \%$ of the respondents claim that a talented person is one who has exceptional, rare talents (an outstanding scientist). For $9 \%$ of the respondents, 
a talented person is a specialist who is difficult to be replaced. About $7 \%$ believe that a talented person is an employee who can influence the present and future successes and achievements of his/her organization. Surprisingly, only $4 \%$ of the respondents consider a person with unusual but superfluous talents, not affecting the improvement of the lives of others or the functioning of a company, as a talent. Only $2 \%$ say that the best-performing employee is a talented person. Thus, the hypothesis that talent is an individual feature that is variable over time has been proved. It is shaped by external and internal factors. The internal factors include skills that change through the pursuit of profession. Motivation belongs among external factors. If a person with a high developmental, entrepreneurial and creative potential is recognized as a talent, it should be assumed that environmental factors influence the development of talent. These are, first and foremost, supervisors and associates who "sculpt" the organizational culture of a company. The development of "talent" is also affected by tasks (from simple to more and more complex) and occurrence of completely accidental events

Due to entrepreneurship and creativity, talented people are capable of fulfilling new tasks, taking risks and implementing new ideas. By acting in this way, the employees create the "added value" of a company. The labor market expects an employee to take initiatives in search for new solutions to problems, as well as flexibility and mobility.

In the next question, an attempt was made to identify the persons responsible for the implementation of the "talent management" program in the organization. The results are shown in Figure 7.

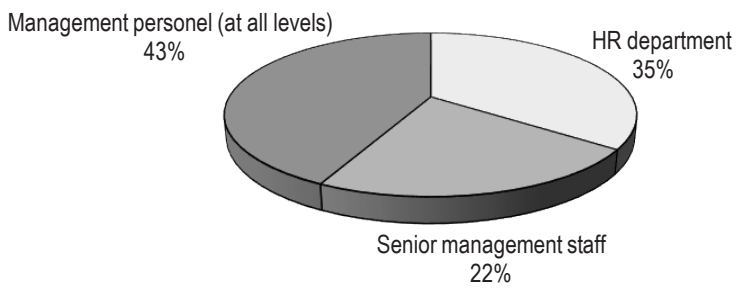

Figure 7. Respondents' opinions regarding responsibility for implementing the "talent management" program in an organization Source: own study.

A significant part of the respondents (43\%) puts responsibility for the implementation of "talent management" plans in organizations on management staff at all levels. According to the respondents, they ought to be the main creators of employee development through the implementation and supervision of "talent management" programs. Subordinates expect their superiors to be involved in developing employee competences and designing individual career paths. It should be remembered that the lower management is "closest" to employees. They must therefore have knowledge of employees' weaknesses and strengths. Managers should not be afraid to employ people who are more skilled than them; instead, they are supposed to develop their potential and use their talents. It must not be forgotten that it is the managers who shape the company's organizational culture, where the company's development is a priority. According to approximately $35 \%$ of the respondents, HR departments are to be liable for the implementation of "talent management" programs. Only one in four respondents claim (over $22 \%$ ) that the senior management staff should bear responsibility for implementing employee development programs. 
The research shows that the "talent management" programs do not function in companies in the Lower Silesia Voivodeship. Opinions on the implementation of "talent management" programs are presented in Figure 8.

About $88 \%$ of the respondents expressed the opinion that their company did not have a "talent management" program or had no knowledge about it. It can therefore be assumed that most companies do not implement such programs. Only $5 \%$ of the respondents indicated that the "talent management" program had functioned in their company for one to three years.



Figure 8. Opinions on implementation of talent management programs

Source: own study.

Among the respondents, $7 \%$ said that the "talent management" program had functioned in their organization for more than 3 years. It is satisfactory, therefore, that the number of organizations implementing development programs is growing. Talent management programs operate only in large companies employing over 100 employees (Figure 9). Most "talent management" programs have operated in these organizations for over three years. A quarter of companies introduced "talent management" programs during the past year. This proves the responsibility of the top management and awareness of the role of human capital in the era of competition. They are aware that, their development can achieve a competitive advantage through investing in human resources. In addition, by introducing "talent management" programs, the top management of the organization gives a positive signal to employees in the form of career perspectives.

"Talent management" programs are not implemented in smaller organizations.

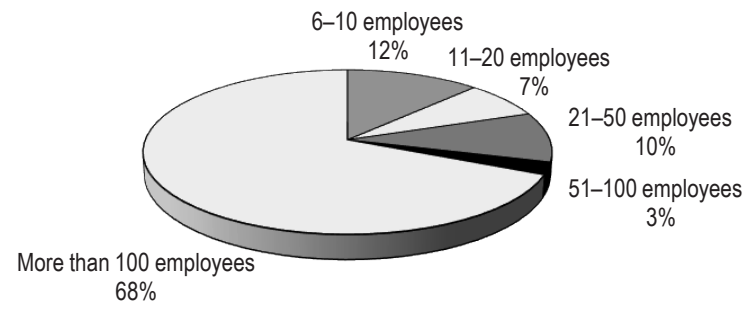

Figur $\mathrm{G}$. Functioning of talent management depending on the number of employees

Source: own study. 
The diagnostic survey attempted to determine what constitutes the basis for qualifying employees for "talent management" programs. This is shown in Figure 10.

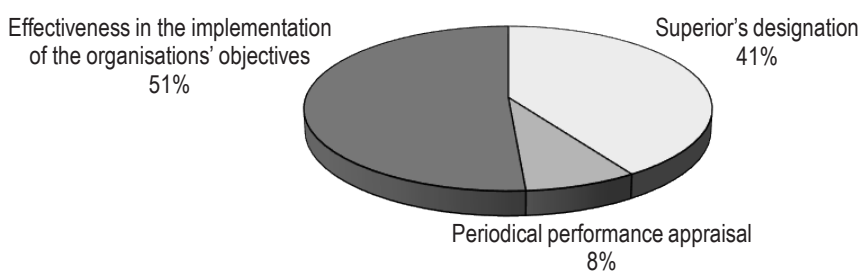

Figure 10. Opinions on the qualification of employees to "talent management" programs

Sourc: own study.

Over half of the employees (51\%) are convinced that they have been qualified for the "talent management" program thanks to their effectiveness in achieving the organization's objectives. Almost $41 \%$ of the participants in the "talent management" project claim that they participate in the project owing to designation of their superiors. Only $7.9 \%$ of the participants of the program believe that their qualification was determined by a high evaluation of periodical appraisal. It can therefore be assumed that supervisors duly perform managerial functions, know employees and care for their development. An important element is the selection of employees for the program. If people who do not have "talents" are qualified for them, the entire program will lose credibility in the eyes of other employees. When introducing development programs, it should be suitably signaled to the staff that such action makes sense. The organization's authorities should treat these programs as an investment.

Anxiety is aroused by the fact that every eleventh employee was included in the program thanks to the high periodical appraisal. It can therefore be assumed that in these organizations the employee assessment does not fulfill the basic function, namely it does not provide the employees with information about the quality of work performed by them. This periodical assessment of an employee should be the basis for designing the career trajectory. The focus should be on identifying errors in the assessment process (regularity, objectivity and criteria).

Despite the fact that in the majority of companies the "talent management" programs have not been implemented, the "talented" people are identified and motivated by their superiors. This is shown in Figure 11.

One-third of the respondents, over $29 \%$, stated that talented employees are not motivated in their organizations. A large group of employees $(22 \%)$ are motivated materially by granting them financial bonuses. About $19 \%$ of respondents said that talented people in their companies are motivated by extending their powers and responsibilities. They perform tasks that determine the functioning of the organization on the market and provide an advantage over the competition. According to the respondents, talented people have greater freedom in action $(9.5 \%)$ and receive appreciation on the group forum (9.2\%). In a few of the companies, flexible working time for talented people is preferred (7.1\%). The reason for not implementing the "talent management" programs is probably the lack of financial resources for the development of employees, as well as the limited number of posts, which is connected with the possibilities of transferring employees to other posts. At the same time, management approves and rewards spontaneous subordinates (talented people), despite the fact that such action is not always consistent with applicable procedures, regulations or stereotypes. 


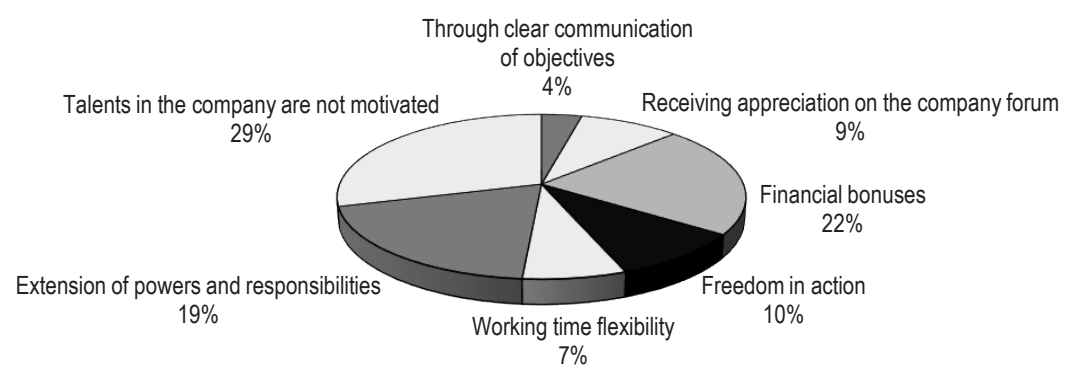

Figure 11. Opinions on motivating talented people

Source: own study.

The respondents were also asked a key question in the survey, namely whether they felt talented. The answers are shown in Figure 12. Most of the respondents considered themselves talented (61\%) while $39 \%$ said they did not have any talents. In the respondents' view talents are:

- creativity in solving problems,

- organizing skills,

- the ability to learn quickly and the willingness to learn,

- ability to cooperate in a team and manage it,

- the ability to resolve conflicts,

- doing several things at the same time,

- establishing interpersonal contacts,

- language skills,

- artistic skills.

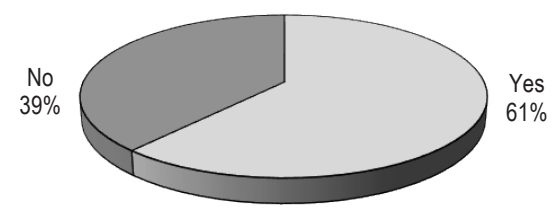

Figure 12. Respondents' opinions on whether they have talents

Source: own study.

The talents indicated by the respondents as talents can be counted among the qualities and skills of "a good manager". It must not be forgotten that managers are the creators of organizational culture, create working conditions and have an impact on both employees and clients. At the same time, it should be borne in mind that due to the managerial skills of the managerial staff, the existence of an organization, its survival or development in a turbulent environment is possible. In addition, it should be added that management is a difficult task and often releases tension, causes stress and frustration. When analyzing the results of research, it should be taken into account that the subjects are students at the faculty of Management. Therefore, it can be assumed that, having 
such talents, they pursue their passions, and they find professional fulfillment. Moreover, the respondents indicated barriers in developing talents:

- lack of time for development,

- no chance for development due to the place of residence (village),

- lack of willingness to improve one's skills,

- lack of any talents,

- low level of self-esteem.

\section{Conclusions}

Summarizing the issue of "talent management", it should be stated that talents require appropriate conditions to be revealed and developed. It is necessary to get to know the employee's activity area in which information for developing talents will be obtained. Implementation of "talent management" programs is conducive primarily to increasing the company's competitiveness in the market, supporting organizational culture, retaining talented employees in a company, ensuring the inflow of new talented employees as well as creating a positive image on the external labor market

Innovative programs make a company able to prepare plans for the succession of positions, develop employee competencies at all levels of an organization, improve the motivation of employees through clear and transparent principles of career path design, employ persons with exceptional skills that provide unique knowledge to the organization.

The determination and individual desire to develop an employee are usually sufficient to develop the potential. With appropriate support from superiors, this process is carried out much faster. The main effect of talent programs is "acceleration"

Therefore, smaller companies should be encouraged to implement development programs. Based on the research, a number of important conclusions have been drawn:

a) managers of all levels should participate in the diagnosis of employee talents;

b) employees with the greatest development potential, creative and entrepreneurial should be considered talented persons;

c) the idea of the "talent management" process of should be disseminated in smaller companies;

d) clearly defined rules and criteria should apply in the selection for development programs;

e) when qualifying employees for development programs, the significance of employee periodical appraisal of should be increased;

f) financial as well as non-material incentives should be used to motivate talented people.

It should be remembered that there is no one universal "talent management" program. Each company is a different organizational culture and a different development strategy. Development programs vary from each other and are adapted to current and future needs of a company. In practice, this means that talents are defined differently by individual organizations. 


\section{References}

Antczak, Z. (2010). Rozwój pracowników. In: T. Listwan (ed.), Zarządzanie kadrami. Warszawa: C.H. Beck.

Chełpa, S. (2015). Samorealizacja talentów - możliwości i ograniczenia interpersonalne. In: S. Borkowska (ed.), Zarządzanie talentami (pp. 26-28). Warszawa: Difin.

Davis, T. (2010). Ewaluacja talentu. Nowa strategia zarządzania talentami w organizacji. Warszawa: Wolters Kluwer.

Głowacka-Stewart, K. (2016). Zarządzanie talentami. Warszawa: Raport badawczy.

Jabłoński, M. (2015). Istota, funkcje i praktyki zarządzania talentami pracowniczymi. Zeszyty Naukowe Wyższej Szkoły Bankowej w Poznaniu, 60 (3), 31-48.

Kopeć, J. (2012). Zarządzanie talentami w przedsiębiorstwie. Kraków: Wydawnictwo Uniwersytetu Ekonomicznego w Krakowie.

Mikuła, B. (2012). Zachowania organizacyjne w kontekście zarządzania wiedzą. Kraków: Uniwersytet Ekonomiczny w Krakowie.

Pocztowski, A. (2008). Zarządzanie talentami w organizacji. Kraków: Oficyna Wolters Kluwer Business.

Sękowski, A.E. (2004). Psychologia zdolności. Współczesne kierunki badań. Warszawa: Wydawnictwo Naukowe PWN.

Cite this anticle aS: Balcerzyk, R., Balcerzyk, D. (2018). Talent management in the context of human capital. European Journal of Service Management, 4 (28/2), 35-46. DOI: 10.18276/ejsm.2018.28/2-04. 